\title{
The pepsinolytic hydrolysate from Johnius belengerii frame inhibited LPS-stimulated production of pro-inflammatory mediators via the inactivating of JNK and NF-KB pathways in RAW 264.7 macrophages
}

\author{
Seong-Yeong Heo ${ }^{1,2}$, Seok-Chun $\mathrm{Ko}^{2}$ and Won-Kyo Jung ${ }^{1,2^{*}}$ (D)
}

\begin{abstract}
The objective of this study was to investigate the anti-inflammatory effects of the pepsinolytic hydrolysate from the fish frame, Johnius belengerii, on lipopolysaccharide (LPS)-stimulated RAW 264.7 macrophages. The J. belengerii frame hydrolysate (JFH) significantly suppressed nitric oxide (NO) secretion on LPS-stimulated RAW264.7 macrophages. Moreover, the JFH markedly inhibited the levels of protein and mRNA expression of inducible nitric oxide synthase (iNOS) and cyclooxygenase-2 (COX-2). Furthermore, the LPS-stimulated mRNA expression of pro-inflammatory cytokines, including tumor necrosis factor (TNF)- $\alpha$, interleukin (IL)-1 $\beta$, and IL-6 was downregulated when cells were cultured with the JFH. The JFH significantly reduced the phosphorylation of c-Jun N-terminal kinase (JNK) and the translocation of nuclear factor-kappa B (NF-KB) in macrophages. As the result, the JFH has the potential antiinflammatory activity via blocking the JNK and NF-kB signal pathways.
\end{abstract}

Keywords: Anti-inflammatory, Fish frame, Pepsinolytic hydrolysis, RAW 264.7 macrophages, MAPKs, NF-kB

\section{Background}

Inflammatory response is a protective mechanism employed by living tissues against physiological and pathological antigens such as injurious and infectious stimulus (Oh et al. 2017). However, this process persists for a long period of time; it can lead to cardiovascular diseases, diabetes, arthritis, cancer, neurological diseases, pulmonary diseases, and autoimmune diseases (del Carmen Millán-Linares et al., 2014). Macrophages play a pivotal role as the host defense in the immune system (Jovanovic et al. 1998). In response to lipopolysaccharide (LPS) or interferon gamma (IFN- $\gamma)$, macrophages produce and secrete nitric oxide $(\mathrm{NO})$ and prostaglandin $\mathrm{E}_{2}\left(\mathrm{PGE}_{2}\right)$, which are synthesized by inducible nitric oxide synthase (iNOS)

\footnotetext{
* Correspondence: wkjung@pknu.ac.kr

${ }^{1}$ Department of Biomedical Engineering and Center for Marine-Integrated Biomedical Technology (BK21 Plus), Pukyong National University, Busan 48513, Republic of Korea

${ }^{2}$ Marine-Integrated Bionics Research Center, Pukyong National University, Busan 48513, Republic of Korea
}

and cyclooxygenase-2 (COX-2), respectively, as well as pro-inflammatory cytokines such as including tumor necrosis factor- $\alpha$ (TNF- $\alpha$ ), interleukin (IL)- $1 \beta$, and IL6 (Yoon et al. 2011).

Food protein hydrolysates generated by proteolytic enzyme treatment have been reported to possess nutraceutical potentials with beneficial human health. As the numerous studies have shown, the food protein hydrolysates have several biological activities, including anti-cancer (Nguyen et al. 2012), anti-hypertension (Ngo et al. 2015), osteoblastic differentiation (Nguyen et al. 2014), anti-inflammation, and anti-oxidant (Cattaneo et al. 2014). Among them, the health benefits of fish and shellfish have been reported with antiinflammatory and anti-oxidative activity through production by enzymatic hydrolysis (Halldorsdottir et al. 2014; Holen et al. 2016; Qian et al. 2012).

Johnius belengerii is a commercial product with a high consumption of sea foods like fish cutlet in the USA, Australia, Europe, Korea, and Japan (Jung and Kim 2007). Although $J$. belengerii markets have quickly expanded, 
fishery byproducts including fish frame have rarely been used. According to the previous study, Kim et al. (2007) reported anti-oxidative effect of pepsinolytic hydrolysate from J. belengerii frame. However, it has not yet reported on anti-inflammatory activity of $J$. belengerii hydrolysate on LPS-stimulated macrophages. It is a superior candidate because oxidative stress was correlated with a wide spectrum of diseases, including chronic inflammation and cancers (Reuter et al. 2010). Therefore, the present study was investigated to evaluate the anti-inflammatory effects of $J$. belengerii frame hydrolysate (JFH) in lipopolysaccharide (LPS)-stimulated RAW264.7 macrophages, as well as the mechanism underlying this effect.

\section{Methods}

\section{Materials}

J. belengerii frames were donated from Charmson Food Co. Ltd. (Busan, Korea). Pepsin from porcine gastric mucosa, 3(4, 5-dimethylthiazol-2-yl)-2, 5-diphenyltetrazolium bromide (MTT) Griess reagent, and LPS were purchased from Sigma Aldrich (Sigma Aldrich, St. Louis, USA). Dulbecco's minimum Eagle's medium (DMEM), fetal bovine serum (FBS), penicillin/streptomycin, and other materials used in cell culture experiment were purchased from $\mathrm{GIBCO}^{\mathrm{m}}$, Invitrogen Corporation, USA. The specific antibodies used for Western blot analysis were purchased from Santa Cruz Biotechnology (Santa Cruz, Ca, USA) and Ameresham pharmacia biosciences (Piscataway, NJ, USA).

\section{Preparation of pepsinolytic hydrolysate of fish frame, J. belengerii}

The fish frame powder was digested with pepsin (enzyme/substrate ratio, 1/100; substrate concentration, $1 \%$ ) in $5 \%$ acetic acid solution ( $\mathrm{pH} 2.0$ ) according to our previous method (Jung and Kim 2007). After incubation at $100{ }^{\circ} \mathrm{C}$ for $10 \mathrm{~min}$ to inactivate enzyme, the solution was filtered through an ashless Whatman No. 41 filter paper. After removing insoluble materials by centrifuging at $3000 \times g$ for $20 \mathrm{~min}$, soluble hydrolysate in supernatant was lyophilized to obtain a JFH dry powder. The JFH was kept $-70{ }^{\circ} \mathrm{C}$ for further experiments.

\section{Cell culture}

RAW 264.7 macrophages were obtained from the American Type of Culture Collection (Rockville, MD, USA). Cells were grown in DMEM supplemented with $10 \% \mathrm{FBS}, 1 \%$ penicillin $(100 \mathrm{U} / \mathrm{ml})$, and streptomycin $(100 \mu \mathrm{g} / \mathrm{ml})$ at $37{ }^{\circ} \mathrm{C}$ in $5 \% \mathrm{CO}_{2}$-humidified air environment. Cells were sub-cultured every 3 days.

\section{Cytotoxic evaluation using MTT assay}

MTT assay was performed to assess the cytotoxicity of RAW 264.7 macrophages. Briefly, cells were seeded on the plate and culture with various concentrations of the JFH $(10,50$, and $100 \mu \mathrm{g} / \mathrm{ml})$ for $24 \mathrm{~h}$. MTT solution was added at each well. After incubation for $4 \mathrm{~h}$, the supernatants were aspirated. The formazan crystal was dissolved in dimethyl sulfoxide (DMSO), and the absorbance was measured with a microplate reader (PowerWave XS2, BioTek Instruments, Inc., USA) at $550 \mathrm{~nm}$.

\section{Determination of NO production}

NO levels in the culture supernatants were determined by measuring nitrite, which is a major stable product of NO, using the Griess reagent. After the pre-incubation of the RAW 264.7 macrophages with various concentrations of the JFH and LPS $(0.25 \mu \mathrm{g} / \mathrm{ml})$ for $24 \mathrm{~h}$, the quantity of nitrite accumulated in the culture medium was measured as an indicator of NO production. Briefly, $100 \mu \mathrm{l}$ of cell culture medium was mixed with $100 \mu \mathrm{l}$ of Griess reagent; the mixture was incubated at room temperature for $10 \mathrm{~min}$, and the absorbance at $540 \mathrm{~nm}$ was measured in a microplate reader. Fresh culture medium was used as a blank in every experiment.

\section{Western blot analysis}

The cells were seeded in 6-well culture plates at a density of $1 \times 10^{6}$ cells/well and grown in $2 \mathrm{ml}$ of DMEM for $24 \mathrm{~h}$. To determine iNOS and COX-2, cells were stimulated with LPS $(0.25 \mu \mathrm{g} / \mathrm{ml})$ in the presence of JFH $(10,50$, and $100 \mu \mathrm{g} / \mathrm{ml}$ ) for $24 \mathrm{~h}$. On the other hand, signal pathways (MAPKs and NF- $\mathrm{kB}$ ) determined that cells were stimulated with LPS $(0.25 \mu \mathrm{g} / \mathrm{ml})$ in the presence of JFH $(10,50$, and $100 \mu \mathrm{g} / \mathrm{ml}$ ) for $30 \mathrm{~min}$. After that, all steps are same to following below processes. Then, the cells were collected and washed twice with PBS. The cells were lysed in lysis buffer $\left(20 \mathrm{mM}\right.$ Tris, $5 \mathrm{mM}$ EDTA, $10 \mathrm{mM} \mathrm{Na} \mathrm{P}_{2} \mathrm{O}_{7}, 100 \mathrm{mM}$ $\mathrm{NaF}, 2 \mathrm{mM} \mathrm{Na} \mathrm{VO}_{4}, 1 \% \mathrm{NP}-40,10 \mathrm{mg} / \mathrm{ml}$ aprotinin, $10 \mathrm{mg} / \mathrm{ml}$ leupeptin, and $1 \mathrm{mM}$ PMSF) for $60 \mathrm{~min}$ and then centrifuged at $16,000 \times g$ and $4{ }^{\circ} \mathrm{C}$ for $15 \mathrm{~min}$. The protein concentrations were determined using the $\mathrm{BCA}^{\mathrm{mu}}$ protein assay kit. The lysate containing $40 \mu \mathrm{g}$ of protein was subjected to electrophoresis on a sodium dodecyl sulfate (SDS)-polyacrylamide gel, and the gel was transferred onto a nitrocellulose membrane. The membrane was blocked with $5 \%$ nonfat dry milk in TBS-T $(25 \mathrm{mM}$ Tris$\mathrm{HCl}, 137 \mathrm{mM} \mathrm{NaCl}, 2.65 \mathrm{mM} \mathrm{KCl}$, and $0.05 \%$ Tween 20 , $\mathrm{pH}$ 7.4) for $2 \mathrm{~h}$. The primary antibodies (glyceraldehyde 3phosphate dehydrogenase; GAPDH, Lamin B, iNOS, COX-2, p-ERK, ERK, p-p38, p38, p-JNK, JNK, p-I-kB, I$\kappa \mathrm{B}, \mathrm{p} 65$, and $\mathrm{p} 50)$ were used at a 1:1000 dilution. The membranes were incubated with the primary antibodies at $4{ }^{\circ} \mathrm{C}$ overnight, washed with TBS-T, and then incubated with the secondary antibodies at 1:3000 dilutions. The signals were developed using an ECL Western blotting detection kit and quantified using Davinci $\mathrm{K}$ chemi-doc imaging system (Young Hwa scientific Co. LTD., Seoul, 
Korea), and protein expression was quantified by Image J software (Wayne Rasband, NIH, Bethesda, Md., USA).

\section{Reverse transcriptase polymerase chain reaction (RT-PCR) analysis}

The cells were seeded in 6-well culture plates at a density of $1 \times 10^{6}$ cells/well and grown in $2 \mathrm{ml}$ of DMEM for $24 \mathrm{~h}$. The total RNA from the LPS-stimulated RAW 264.7 macrophages in the presence or absence of the JFH was extracted using the TRIzol reagent. After treatment of TRIzol, the suspension was mixed with chloroform and centrifuged at $18,000 \times g$ for $10 \mathrm{~min}$ at $4{ }^{\circ} \mathrm{C}$. The aqueous phase was separated and RNA in the phase was precipitated by mixing with isopropyl alcohol and centrifuged at $18,000 \times g$ for $10 \mathrm{~min}$ at $4{ }^{\circ} \mathrm{C}$. The precipitate was washed with $75 \%$ ethanol, dried, and then dissolved in diethyl pyrocarbonate (DEPC) containing water. The total RNA content was calculated based on the absorbance at $260 \mathrm{~nm}$, and the quality was confirmed. Equal amounts of RNA were used for each cDNA synthesis reaction according to the manufacturer's instruction. Then, $2 \mu \mathrm{l} \mathrm{cDNA}$ was used for reverse transcription and amplified by PCR using the access RT-PCR system. PCR was performed using primers for mouse iNOS, COX-2, TNF- $\alpha$, IL-1 $\beta$, IL6 , and GAPDH. The PCR was performed using selective primers for the iNOS (5'-ATGTC CGAAGCAAACATC AC-3' and 5' -TAATGTCCAGGAA GTAGGTG-3'), CO X-2 (5'-GGGGTACCTTCCAGCTGTCAAAA TCTC-3' and $5^{\prime}$-GAAGATCTCGCCAGGTACTCACCTG-3'), TN F- $\alpha \quad 5^{\prime}$-ATGAGCACAGAAAGCATGA TC-3' and $5^{\prime}$ TACAGGCTTGTCACTCGAATT-3'), IL-1 $\beta$ (5'-ATGGCAACTGTTCCTGAACTCAACT-3' and 5' ${ }^{\prime}$-TTTCCTT TCTTAGATATGGACAGGAC-3'), IL-6 (5' -ATGAGCA CAGAAAGCATGATC-3' and 5' ${ }^{\prime}$-TACAGGCTTGTCAC TCGAATT-3'), and GAPDH (5'-TTTGTGATGGGTGT GAACCACGAG-3' and 5'-GGAGACAACCTGGTCCT CAGTGTA-3'). The following PCR conditions were applied for all amplifications by 25 cycles of $95{ }^{\circ} \mathrm{C}$ for $30 \mathrm{~s}$ (denaturing), $58{ }^{\circ} \mathrm{C}$ for $30 \mathrm{~s}$ (annealing), and $72{ }^{\circ} \mathrm{C}$ for $30 \mathrm{~s}$ (primer extension). Following amplification, portions of the PCR reactions were electrophoresed on an agarose gel for $20 \mathrm{~min}$ at $100 \mathrm{~V}$. The gels were visualized after staining with EtBr using UNOK-8000s Gel Manager System (Biotechnology, Seoul, Korea), and mRNA expression was quantified by Image J software.

\section{Statistical analysis}

All data were represented as the mean \pm standard deviation (SD). Statistical comparisons of the mean values were performed by analysis of variance (ANOVA), followed by Duncan's multiple range test using SPSS software. Statistical significance was considered at $p<0.05$.

\section{Results and discussion}

Cytotoxicity of the JFH and its inhibitory effect on NO production

In accordance with our previous study, the JFH was mainly composed of $63.95 \%$ protein (Jung and Kim 2007). Compared with previous studies, protein content of JFH was determined lower than Sardina pilchardus (85.8\%), Trachurus mediterraneus (86.3\%), Mallotus villosus (72.4\%), Clupea harengus (77.0\%), and Salmo salar (88.39\%) because fish frame contains amount of ash (Chalamaiah et al. 2012; Morales-Medina et al. 2016). To prepare a soluble hydrolysate without inorganic precipitate, we performed centrifugation to remove insoluble materials and filtration through $0.2-\mu \mathrm{m}$ syringe filter (Toyo Roshi Kaisha Ltd., Tokyo, Japan). Then, protein concentration of the soluble hydrolysate was measured. At the result, we determined that the soluble hydrolysate consists of $97.9 \pm 0.87 \%$ protein concentration and used further experiments.

Prior to evaluation of the NO inhibitory effect of JFH, we first examined its cytotoxic effect in LPS-stimulated RAW 264.7 macrophages using MTT assay. As shown in Fig. 1a, no significant cytotoxic effects were observed in RAW 264.7 macrophages, which were treated with various concentrations of JFH $(10,50$, and $100 \mu \mathrm{g} / \mathrm{ml})$ in the presence of LPS. Thus, those concentrations were used in subsequent experiments.

To evaluate whether the JFH suppressed the production of LPS-stimulated NO, RAW 264.7 macrophages were stimulated with LPS in the absence or presence of the JFH. The result shows that LPS treatment alone markedly induced NO production by the treated cells compared with untreated cells. However, treatment of the various concentrations of JFH $(10,50$, and $100 \mu \mathrm{g} / \mathrm{ml})$ significantly reduced NO production in a concentration-dependent manner (Fig. 1b). The investigation of NO inhibitory effect of protein hydrolysates has already been reported from marine organisms such as Mytilus coruscus (Kim et al. 2013), Ruditapes philippinarum (Lee et al. 2012), Crassostrea gigas (Hwang et al. 2012), Haliotis discus hannai (Qian et al. 2012), and Styela clava (Ko and Jeon 2015). Compared to what has been observed in previous studies, JFH exhibited a similar NO inhibitory effect compared to the hydrolysate of Haliotis discus hannai at the same concentration (Qian et al. 2012) and a more effective NO inhibitory effect than the sweetfish and Mytilus coruscus hydrolysates at the same concentrations (Sung et al. 2012; Kim et al. 2013) in LPSstimulated RAW 264.7 macrophages.

\section{Effect of the JFH on iNOS and COX-2 expression in LPS-stimulated RAW 264.7 macrophages}

NO plays an important role in the immune system. It is produced from L-arginine by the three-member enzyme family including iNOS, endothelial NOS (eNOS), and neuronal NOS (nNOS) (Ryu et al. 2014). In the pathological 


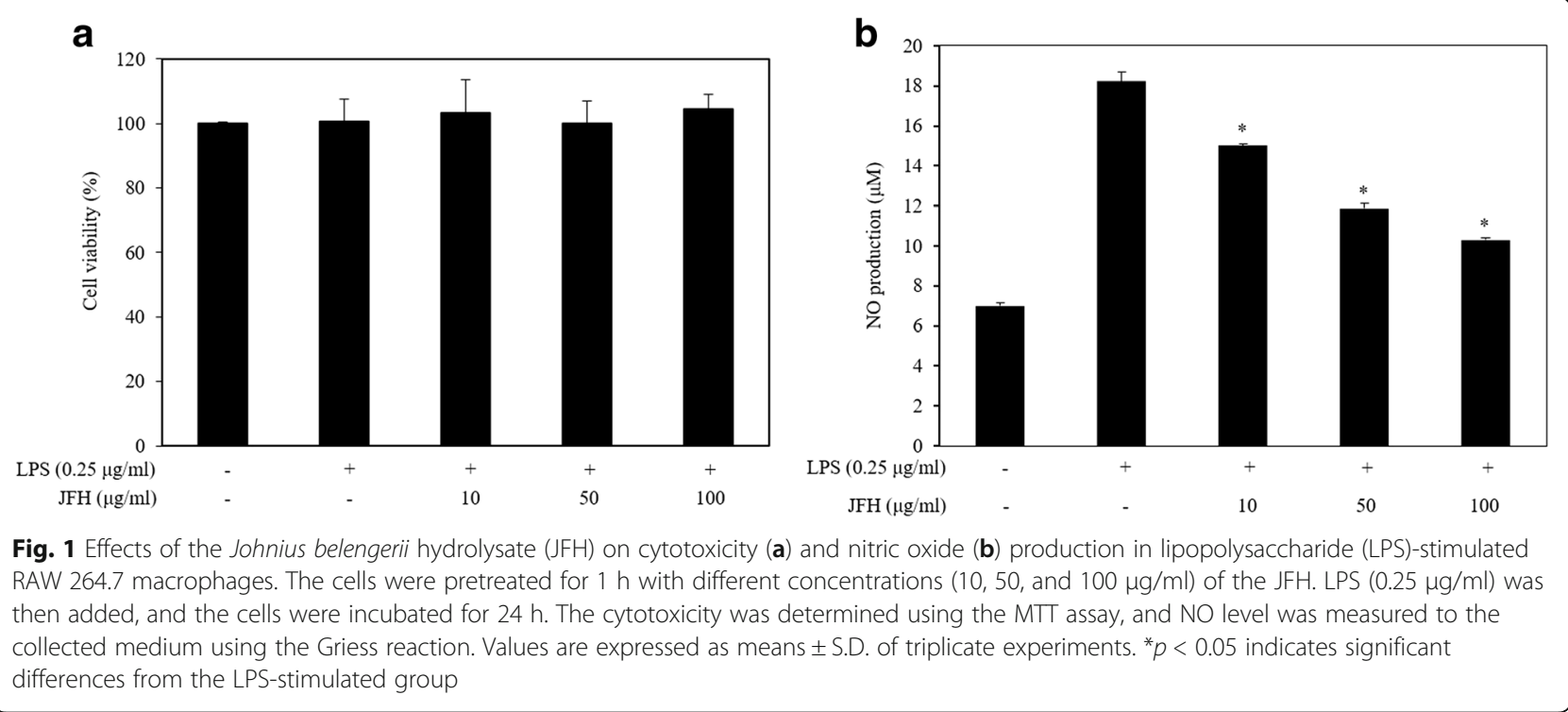

conditions, potent inflammatory mediators, macrophages, were activated and secreted amounts of NO (Choi et al. 2014). According to previous studies, iNOS inhibitors have a similar structure of arginine or exhibit competitive inhibition pattern (Bonnefous et al. 2009). Therefore, we suggest that JFH contains the component of the similar structure to arginine and it has the potential to inhibit iNOS. Moreover, COX-2 also plays a pivotal role that it controls the immune homeostasis including inflammatory response and cancer immune evasion (Wehbi and Taskén 2016). Although NO plays a critical role in defending the pathogen, it can lead to an excessive inflammation and tissue damage due to NO overproduction (Segovia et al. 2013). Therefore, modulation of the inflammatory mediators such as iNOS and COX-2 has been shown to reduce the inflammatory diseases. To determine the mechanism
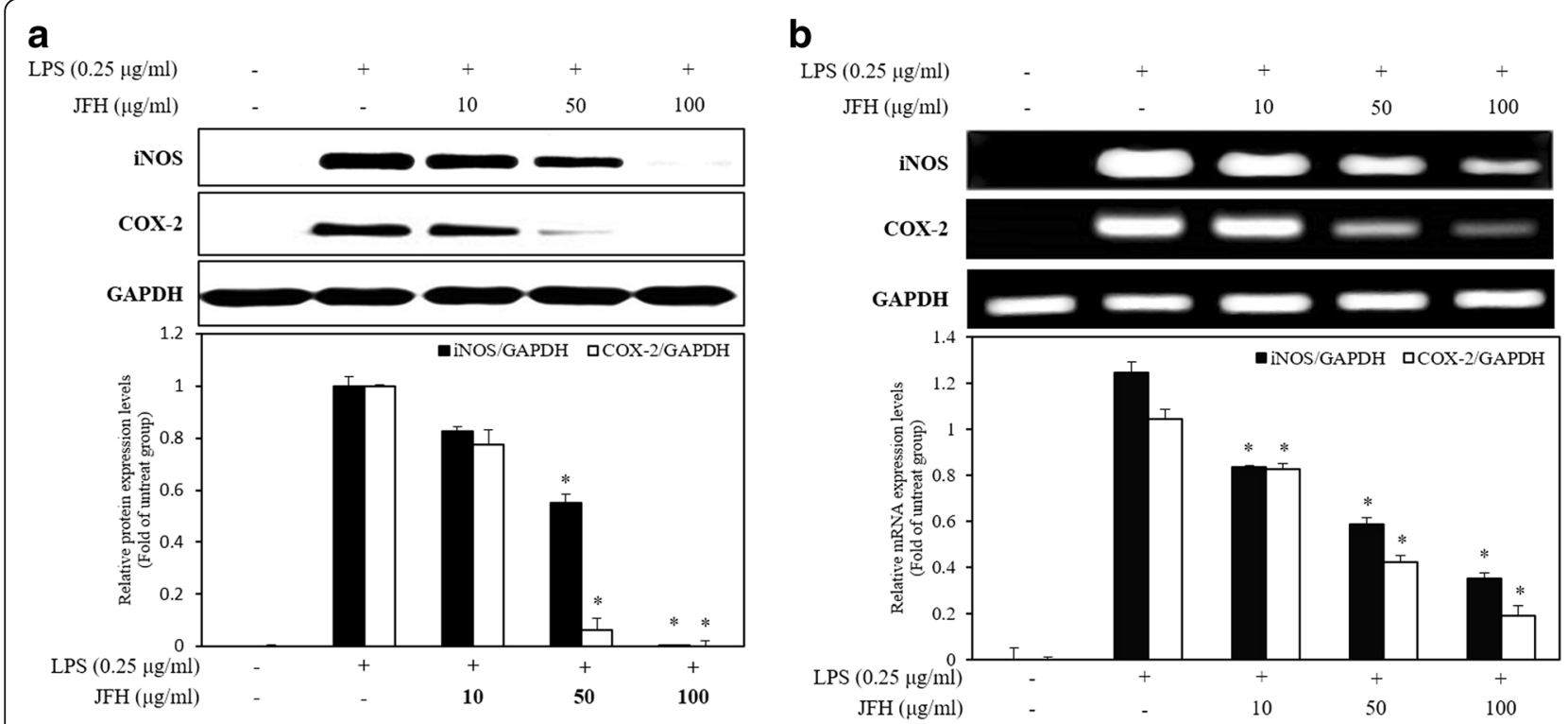

Fig. 2 Inhibitory effect of the JFH in LPS-induced iNOS and COX-2 protein and mRNA expression levels in RAW264.7 macrophages. Cells were stimulated with LPS $(0.25 \mu \mathrm{g} / \mathrm{ml})$ in the presence of JFH $(10,50$, and $100 \mu \mathrm{g} / \mathrm{ml})$ for $24 \mathrm{~h}$. The expression levels of iNOS and COX-2 protein (a) and mRNA (b) were measured by Western blotting and RT-PCR analysis, respectively. iNOS and COX-2 versus GAPDH were measured by densitometer. The density ratio of the protein and mRNA expressed in the LPS-stimulated group were considered to represent 1-fold. The data is expressed as mean folds of the protein and mRNA expression versus LPS-stimulated group. Values are expressed as means \pm S.D. of triplicate experiments. ${ }^{*} p<0.05$ indicates significant differences from the LPS-stimulated group 
involved in the suppression of inflammatory mediators by the JFH on LPS-stimulated RAW264.7 macrophages, we investigated the effect of the JFH on iNOS and COX-2 protein (Fig. 2a) and mRNA (Fig. 2b) expression by Western blotting and RT-PCR analysis. In response to LPS, the protein and mRNA expression of iNOS and COX-2 was markedly increased compared with the untreated cells. However, JFH significantly reduced the levels of the iNOS and COX-2 protein and mRNA expression in a concentration-dependent manner. JFH has more effectively inhibited the levels of iNOS and COX-2 expressions compared to Ruditapes philippinarum (Lee et al. 2012) and Styela clava flesh tissue (Ko and Jeon 2015) hydrolysates. From the results of the above studies, JFH is believed to have a more effective anti-inflammatory effect due to NO inhibition than other marine organisms.

\section{Effect of JFH on expression of pro-inflammatory cytokines} in LPS-stimulated RAW 264.7 macrophages

The pro-inflammatory cytokines, including TNF- $\alpha$, IL$1 \beta$, and IL-6, affect immune cell function, proliferation, and activation (Ahn et al. 2015). According to the Dragan et al. (1998), pro-inflammatory cytokines were closely related to the inflammatory response that they induced NO by activation of the iNOS. Moreover, Nrf2 is the key regulator of suppressing cytokines by LPSinduced oxidative stress like $\mathrm{NO}$ on the macrophages

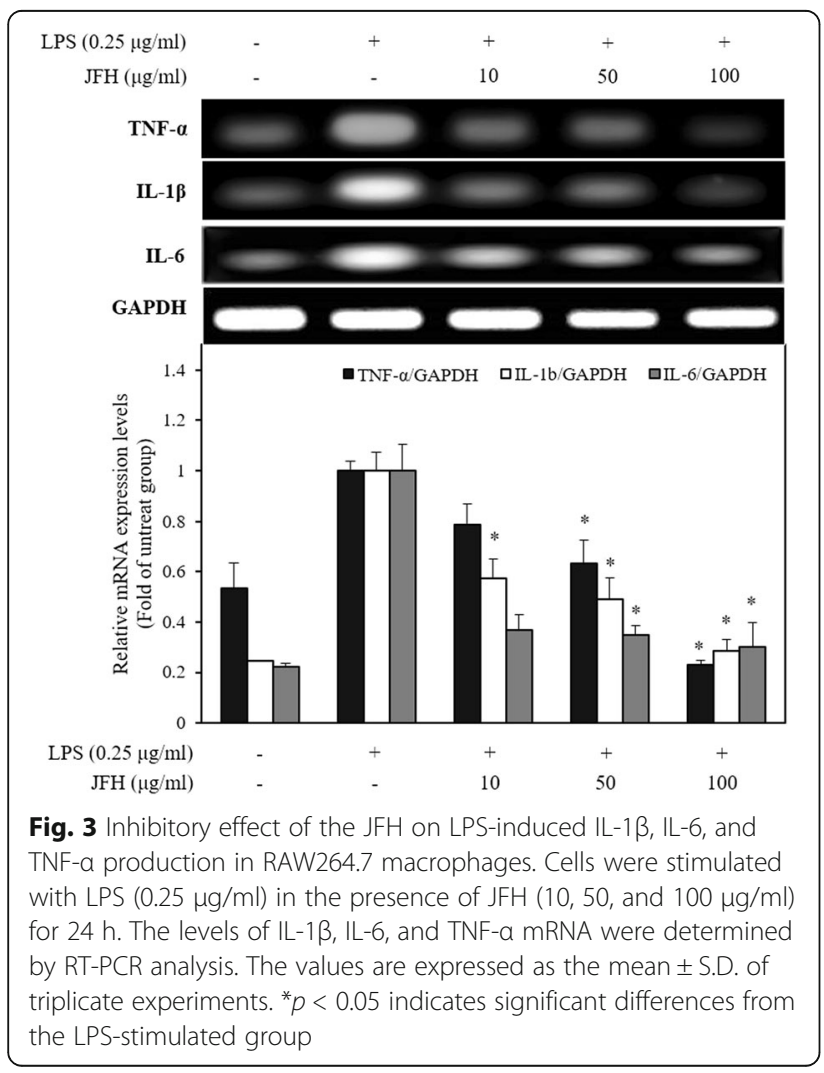

(Kobayashi et al. 2016). Among them, TNF- $\alpha$ is mainly released from LPS-induced macrophages and induces apoptosis, chronic inflammation, and associated diseases (Kim et al. 2011). Moreover, it induces the physiological effects such as septic shock and cytotoxicity as well as inducing IL-1 $\beta$ and IL-6 (Ryu et al. 2014). IL-1 $\beta$ possesses various biological properties and has been shown to induce the inflammatory and immunological responses by releasing prostaglandins (Ligumsky et al. 1990). Multifunctional cytokine of IL-6 also regulates the immune response, hematopoiesis, and inflammation (Ishihara and Hirano 2002). Ishihara and Hirano (2002) reported that IL-6 involves some diseases such as autoimmune diseases, chronic inflammatory proliferative disease, and B cell malignancy. To evaluate the inhibitory effect of the JFH on the pro-inflammatory cytokine production, we performed the expression of mRNA levels of the pro-inflammatory cytokines in the presence of the LPS. As shown in Fig. 3, LPS treatment alone dramatically increased TNF- $\alpha$, IL- $1 \beta$, and IL- 6 mRNA expression levels by the treated cells compared with

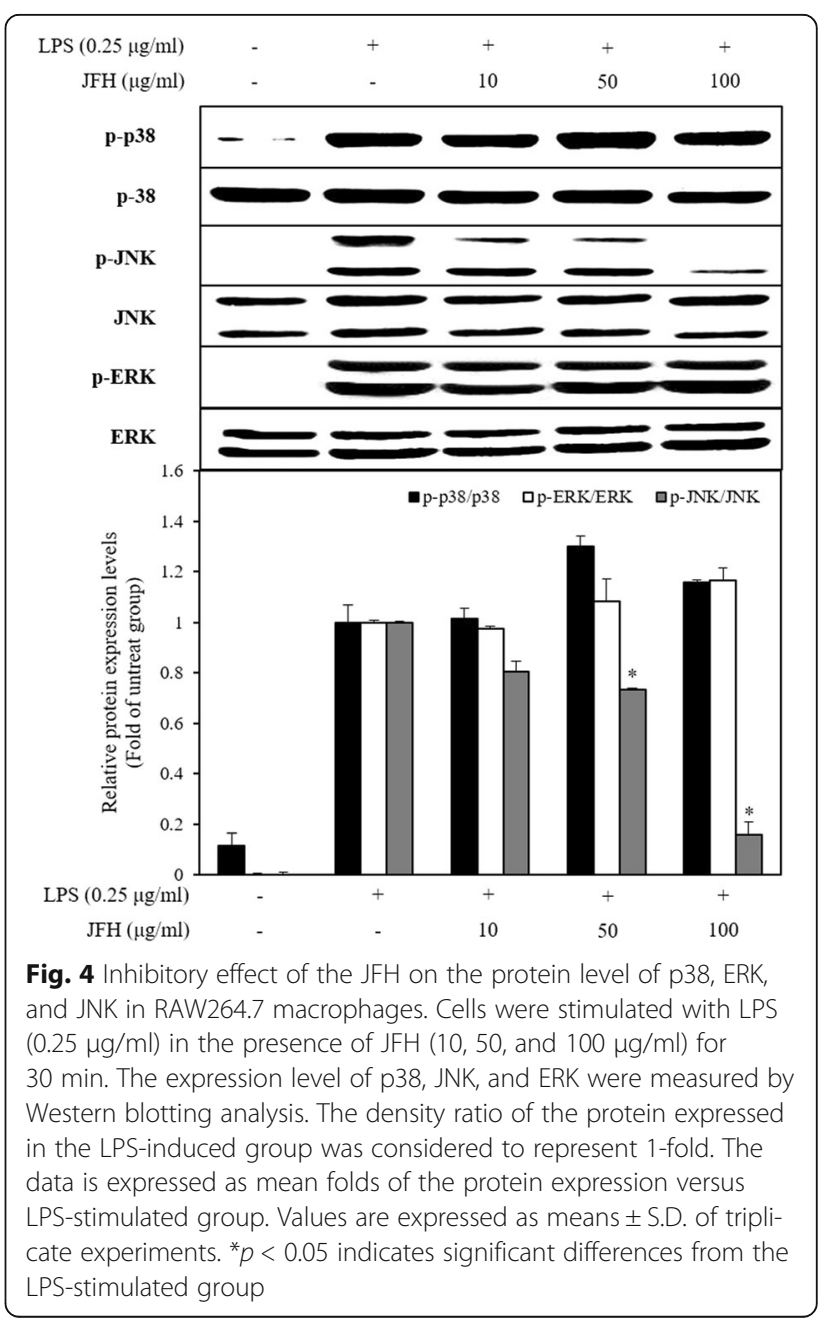


untreated cells. The JFH significantly suppressed TNF- $\alpha$, IL-1 $\beta$, and IL-6 mRNA expression levels by LPSstimulated RAW 264.7 macrophages. These inhibitory effects on pro-inflammatory cytokine transcription and above-described $\mathrm{NO}$ inhibition demonstrated that JFH probably has anti-inflammatory efficacy by inhibiting $\mathrm{Nrf} 2$ as well as below described MAPK and NF- $\mathrm{kB}$. Moreover, JFH has an inhibitory effect of TNF- $\alpha$ and IL$1 \beta$ similar to salmon hydrolysate, but inhibitory effect of IL-6 is better (Ahn et al. 2012). Moreover, JFH has more effectively suppressed cytokine production compared to Plecoglossus altivelis (Sung et al. 2012).

\section{Effects of the JFH on the activation of MAPKs and translocation of NF-KB in LPS-stimulated RAW264.7 macrophages}

MAPKs, including p38 MAPKs, extracellular regulated kinase (ERK), and c-Jun N-terminal kinase (JNK), play an important role that modulated a wide range of physiological processes such as cell growth, differentiation, and cellular response to cytokines through the intracellular signaling cascades (Jeong et al. 2016). The MAPK pathway sequentially activates MAP kinase kinase kinase (MAP3K), MAP kinase kinase (MAP2K), and MAPK (Dennler et al. 2000). During inflammatory processes, MAPK is involved in the synthesis and secretion of inflammatory mediators by LPS stimulation (Kim et al. 2016). According to the previous reports, p38 MAPK possesses the multifarious functions and regulates the expression of iNOS and COX- 2 as well as the secretion of TNF- $\alpha$ in the LPS-induced macrophages (Jeong et al. 2016). ERK also is involved in the production of TNF- $\alpha$ on LPSinduced macrophages (Yuan et al. 2016). Furthermore, JNK is activated by the environmental stress and has implicated the iNOS expression in LPS-stimulated RAW 264.7 (Jeong et al. 2016; Ryu et al. 2014). Thus, MAPK inhibition is a key mechanism for suppression of inflammatory diseases. To elucidate the inhibitory mechanism of the inflammation response, we investigated the effects of the JFH on the activation of MAPKs in LPS-stimulated RAW 264.7 macrophages. The JFH significantly decreased the phosphorylation of LPS-stimulated JNK but not that of p38 and ERK (Fig. 4). JNK phosphorylates several transcription factors including c-Jun, activating transcription factor 2 (ATF-2), and Elk-1 for translocation into the nucleus. Particularly, c-Jun binds in the DNA binding site in the form

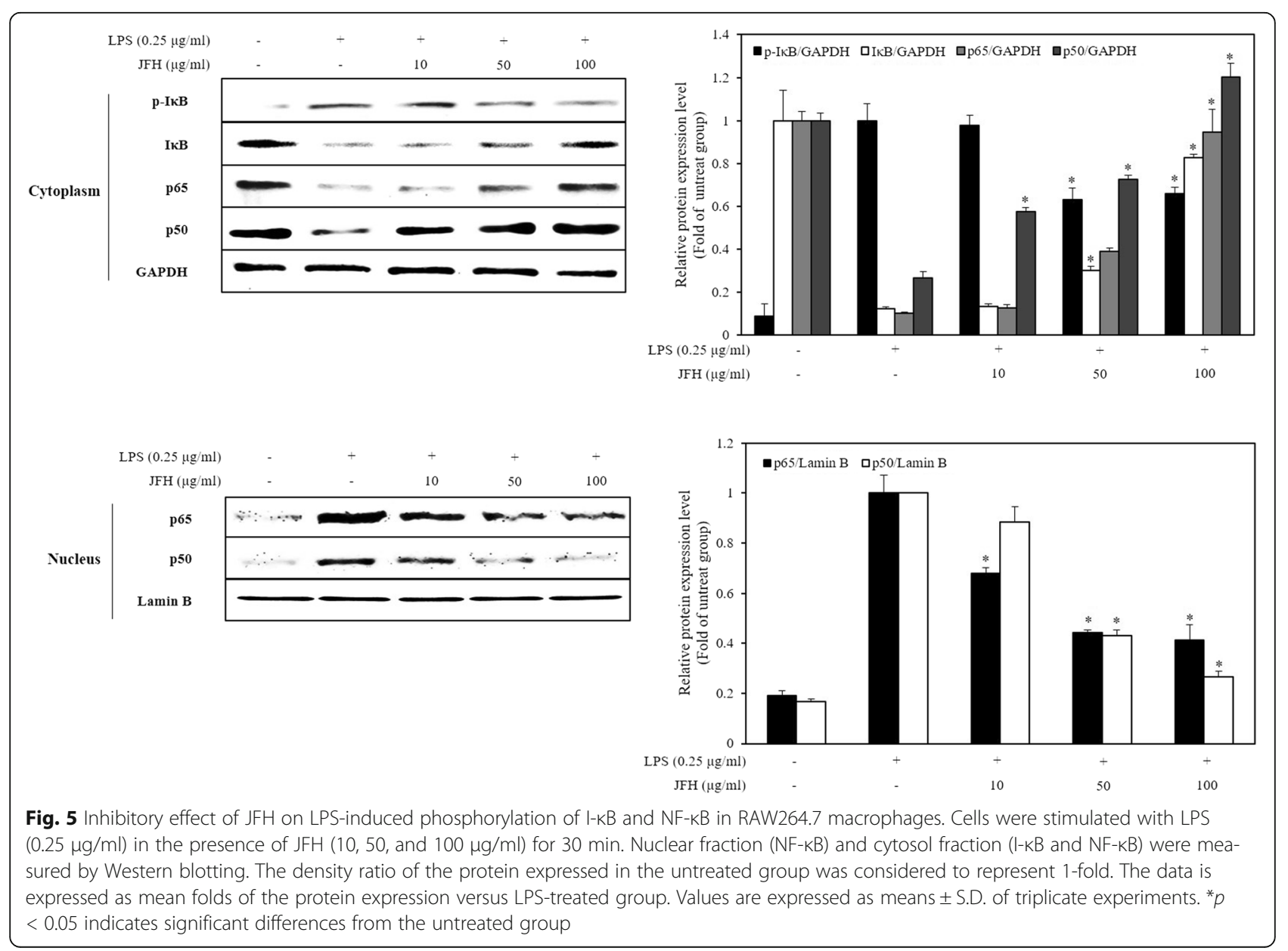


of the homodimer or heterodimer with Fos family and control expression of the pro-inflammatory factors (Dennler et al. 2000). Therefore, we suggest that JFH inhibits transcription factor through phosphorylation of JNK and probably affects MAP3K or MAP2K.

NF- $\mathrm{kB}$ pathway is also a major signaling pathway implicated in regulating the inflammatory mediators in macrophages (Yeom et al. 2015). In LPS-stimulated macrophages, inhibitory factor kappa B (I-kB) is phosphorylated, ubiquitinated, and degraded by the proteasome (Jeong et al. 2016). Thereby, releasing NF-kB from I-kB-NF-kB complex translocates to the nucleus. The translocated NF- $\kappa B$ is involved in the production of pro-inflammatory cytokine, IL-1 $\beta$, and TNF- $\alpha$ and suppression of anti-inflammatory mediators (Tak and Firestein 2001). Furthermore, NF-kB downregulated by phosphorylation of phosphatidylinositol-3-kinase (PI3K)/ Akt and MAPKs as well as anti-oxidant (Kim et al. 2016). Particularly, PI3K/Akt signaling produces reactive oxygen species (ROS) that affects NF- $\mathrm{kB}$ activation. Therefore, inhibition of the translocation of NF- $\mathrm{KB}$ through suppressing $\mathrm{I}-\mathrm{kB}$ phosphorylation and $\mathrm{PI} 3 \mathrm{~K} /$ AKT activation is implicated in the treatment of inflammatory diseases.

Figure 5 shows that LPS treatment alone markedly increased phosphorylation and degradation of $\mathrm{I}-\mathrm{k} B$ in the cytosol and increased translocation of NF- $\mathrm{kB}$ (p65 and p50) in the nucleus, whereas LPS treatment with the JFH significantly decreased phosphorylation of $\mathrm{I}-\mathrm{\kappa} B$ in the cytosol and decreased translocation of NF- $\mathrm{kB}$ (p65 and p50) in the nucleus. Based on the results, JFH affects NF- $\mathrm{BB}$ translocation via JNK phosphorylation and anti-oxidative activity (Kim et al. 2007) as above described. In addition, it probably suppresses activation of PI3K/Akt signal pathway. In comparison with the previous study, $100 \mu \mathrm{g} / \mathrm{ml}$ of JFH has similarly effectively inhibited translocation of NF- $\mathrm{KB}$ by degrading $\mathrm{I}-\mathrm{\kappa} B$ to $200 \mu \mathrm{g} / \mathrm{ml}$ of Plecoglossus altivelis (Sung et al. 2012). Therefore, JFH has an effective anti-inflammatory activity potential due to inflammatory-mediated factors through inhibition of the NF- $\mathrm{kB}$ translocation.

\section{Conclusions}

In the present study, we evaluated the anti-inflammatory effect of the J. belengerii frame hydrolysate (JFH) in LPSstimulated RAW 264.7 macrophages. Based on the results, the JFH exhibited anti-inflammatory activities by reduction of cytokines, iNOS, and COX-2 protein and mRNA expression through inhibition of $\mathrm{I}-\mathrm{kB}$ degradation and NF- $\mathrm{KB}$ translocation and phosphorylation of JNK not p38 and ERK. These results suggest that the JFH could be potential candidates to develop functional foods and pharmaceutical products for the treatment of the inflammatory diseases.

\section{Abbreviations}

ATF 2: Activating transcription factor 2; COX-2: Cyclooxygenase-2;

DEPC: Diethyl pyrocarbonate; DMEM: Dulbecco's minimum Eagle's medium; DMSO: Dimethyl sulfoxide; eNOS: Endothelial nitric oxide synthase;

ERK: Extracellular regulated kinase; FBS: Fetal bovine serum;

GAPDH: Glyceraldehyde 3-phosphate dehydrogenase; IFN- $\gamma$ : Interferon gamma; IL: Interleukin; iNOS: Inducible nitric oxide synthase; I-kB: Inhibitory factor kappa B; JFH: Johnius belengerii frame hydrolysate; JNK: c-Jun Nterminal kinase; LPS: Lipopolysaccharide; MAPKs: Mitogen-activated protein kinases; MTT: 3-(4, 5-dimethylthiazol-2-yl)-2, 5-diphenyltetrazolium bromide; NF-kB: Nuclear factor-kappa B; nNOS: Neuronal nitric oxide synthase; NO: Nitric oxide; $P_{G} E_{2}$ : Prostaglandin $E_{2}$; PI3K: Phosphatidylinositol-3-kinase; ROS: Reactive oxygen species; RT-PCR: Reverse transcriptase polymerase chain reaction; SD: Standard deviation; SDS: Sodium dodecyl sulfate; TNFa: Tumor necrosis factor-a

\section{Acknowledgements}

This research was supported by Pukyong National University Research Fund in 2016.

\section{Funding}

This research was supported by Pukyong National University Research Fund in 2016 .

Availability of data and materials

Not applicable.

\section{Authors' contributions}

SYH and SCK designed this study and drafted the manuscript. WKJ conceived and designed the study and also revised the manuscript. All authors read and approved the final manuscript.

Ethics approval and consent to participate

Not applicable.

\section{Competing interests}

The authors declare that they have no competing interests.

\section{Publisher's Note}

Springer Nature remains neutral with regard to jurisdictional claims in published maps and institutional affiliations.

Received: 20 January 2018 Accepted: 20 February 2018 Published online: 25 May 2018

\section{References}

Ahn CB, Cho YS, Je JY. Purification and anti-inflammatory action of tripeptide from salmon pectoral fin byproduct protein hydrolysate. Food Chem. 2015; 168:151-6.

Ahn CB, Je JY, Cho YS. Antioxidant and anti-inflammatory peptide fraction from salmon byproduct protein hydrolysates by peptic hydrolysis. Food Res Int. 2012:49:92-8

Bonnefous C, Payne JE, Roppe J, Zhuang H, Chen X, Symons KT, Nguyen PM, Sablad M, Rozenkrants N, Zhang Y, Wang L, Severance D, Walsh JP, Yazdani N, Shiau AK, Noble SA, Rix P, Rao TS, Hassig CA, Smith ND. Discovery of inducible nitric oxide synthase (iNOS) inhibitor development candidate KD7332, part 1: identification of a novel, potent, and selective series of quinolinone iNOS dimerization inhibitors that rae orally active in roden pain models. J Med Chem. 2009;52:3047-62.

Cattaneo F, Sayago JE, Alberto MR, Zampini IC, Ordoñez RM, Chamorro V, Pazos A, Isla Ml. Anti-inflammatory and antioxidant activities, functional properties and mutagenicity studies of protein and protein hydrolysate obtained from Prosopis alba seed flour. Food Chem. 2014;161:391-9.

Chalamaiah M, Dinesh Kumar B, Hemalatha R, Jyothirmayi T. Fish protein hydrolysates: proximate composition, amino acid composition, antioxidant activities and applications: a review. Food Chem. 2012;135:3020-38.

Choi YY, Kim MH, Han JM, Hong J, Lee TH, Kim SH, Yang WM. The antiinflammatory potential of Cortex Phellodendron in vivo and in vitro: downregulation of $\mathrm{NO}$ and $\mathrm{NNOS}$ through suppression of NF-KB and MAPK activation. Int Immunopharmacol. 2014;19:214-20. 
del Carmen M-LM, del Mar YM, Alcaide-Hidalgo JM, Millán F, Pedroche J. Lupine protein hydrolysates inhibit enzymes involved in the inflammatory pathway. Food Chem. 2014;151:141-7.

Dennler S, Prunier C, Ferrand N, Gauthier JM, Atfi A. c-Jun inhibits transforming growth factor $\beta$-mediated transcription by repressing Smad3 transcriptional activity. J Biol Chem. 2000;275:28858-65.

Halldorsdottir SM, Sveinsdottir H, Freysdottir J, Kristinsson HG. Oxidative processes during enzymatic hydrolysis of cod protein and their influence on antioxidant and immunomodulating ability. Food Chem. 2014;142:201-9.

Holen E, He J, Araujo P, Seliussen J, Espe M. Hydrolyzed fish proteins modulates both inflammatory and antioxidant gene expression as well as protein expression in a co culture model of liver and head kidney cells isolated from Atlantic salmon (Salmo salar). Fish Shellfish Immun. 2016;54:22-9.

Hwang JW, Lee SJ, Kim YS, Kim EK, Ahn CB, Jeon YJ, Moon SH, Jeon BT, Park PJ. Purification and characterization of a novel peptide with inhibitory effects on colitis induced mice by dextran sulfate sodium from enzymatic hydrolysates of Crassostrea gigas. Fish Shellfish Immun. 2012;33:993-9.

Ishihara K, Hirano T. IL-6 in autoimmune disease and chronic inflammatory proliferative disease. Cytokine Growth Factor Rev. 2002;13:357-68.

Jeong DH, Kim MJ, Kang BK, Ahn DH. Skipjack tuna (Katsuwonus pelamis) eyeball oil exerts an anti-inflammatory effect by inhibiting NF-KB and MAPK activation in LPS-induced RAW 264.7 cells and croton oil-treated mice. Int Immunopharmacol. 2016;40:50-6.

Jovanovic DV, Di Battista JA, Martel-Pelletier J, Jolicoeur FC, He Y, Zhang M, Mineau F, Pelletier JP. IL-17 stimulates the production and expression of proinflammatory cytokines, IL- $\beta$ and TNF-a, by human macrophages. J Immunol. 1998;160:3513-21.

Jung WK, Kim SK. Calcium-binding peptide derived from pepsinolytic hydrolysates of hoki (Johnius belengerii) frame. Eur Food Res Technol. 2007; 224:763-7.

Kim AR, Lee B, Joung EJ, Gwon WG, Utsuki T, Kim NG, Kim HR. 6,6'-bieckol suppresses inflammatory responses by down-regulating nuclear factor-kB activation via Akt, JNK, and p38 MAPK in LPS-stimulated microglial cells. Immunopharm Immunotoxicol. 2016;38:244-52.

Kim EK, Kim YS, Hwang JW, Kang SH, Choi DK, Lee KH, Lee JS, Moon SH, Jeon BT, Park PJ. Purification of a novel nitric oxide inhibitory peptide derived from enzymatic hydrolysates of Mytilus coruscus. Fish Shellfish Immunol. 2013;34: $1416-20$

Kim SY, Je JY, Kim SK. Purification and characterization of antioxidant peptide from hoki (Johnius belengerii) frame protein by gastrointestinal digestion. J Nutr Biochem. 2007;18:31-8.

Kim YK, Jeong EJ, Lee MS, Yoon NY, Yoon HD, Kim JI, Kim HR. Ethanolic extract of Chondria crassicaulis inhibits the expression of inducible nitric oxide synthase and cyclooxygenase-2 in LPS-stimulated RAW 264.7 macrophages. Fish Aquat Sci. 2011;14:275-82

Kim YS, Ahn CB, Je JY. Anti-inflammatory action of high molecular weight Mytilus edulis hydrolysates fraction in LPS-induced RAW264. 7 macrophage via NF-KB and MAPK pathways. Food Chem. 2016;202:9-14.

Ko SC, Jeon YJ. Anti-inflammatory effect of enzymatic hydrolysates from Styela clava flesh tissue in lipopolysaccharide-stimulated RAW 264.7 macrophages and in vivo zebrafish model. Nutr Res Pract. 2015;9:219-26.

Kobayashi EH, Suzuki T, Funayama R, Nagashima T, Hayashi M, Sekine H, Tanaka N, Moriguchi T, Motohashi H, Nakayama K, Yamamoto M. Nrf2 suppresses macrophage inflammatory response by blocking proinflammatory cytokine transcription. Nat Commun. 2016:7:11624.

Lee SJ, Kim EK, Kim YS, Hwang JW, Lee KH, Choi DK, Kang H, Moon SH, Jeon BT, Park PJ. Purification and characterization of a nitric oxide inhibitory peptide from Ruditapes philippinarum. Food Che Toxicol. 2012;50:1660-6.

Ligumsky M, Simon P, Karmeli F, Rachmilewitz D. Role of interleukin 1 in inflammatory bowel disease-enhanced production during active disease. Gut. 1990;31:686-9.

Morales-Medina R, Tamm F, Guadix AM, Guadix EM, Drusch S. Functional and antioxidant properties of hydrolysates of sardine (S. pilchardus) and horse mackerel (T. mediterraneus) for the microencapsulation of fish oil by spraydrying. Food Chem. 2016;194:1208-16.

Ngo DH, Kang KH, Ryu B, Vo TS, Jung WK, Byun HG, Kim SK. Angiotensin-I converting enzyme inhibitory peptides from antihypertensive skate (Okamejei kenojei) skin gelatin hydrolysate in spontaneously hypertensive rats. Food Chem. 2015;174:37-43.
Nguyen MHT, Qian ZJ, Jung WK. Beneficial effect of abalone intestine gastrointestinal digests on osteoblastic MG-63 cell differentiation. J Aquat Food Prod Technol. 2014;23:436-46.

Nguyen VT, Qian ZJ, Jung WK. Abalone Haliotis discus hannai intestine digests with different molecule weights inhibit MMP-2 and MMP-9 expression in human fibrosarcoma cells. Fish Aquat Sci. 2012;15:137-43.

Oh GW, Ko SC, Lee DH, Heo SJ, Jung WK. Biological activities and biomedical potential of sea cucumber (Stichopus japonicus): a review. Fish Aquat Sci. 2017;20:28

Qian ZJ, Kim SA, Lee JS, Kim HJ, Choi IW, Jung WK. The antioxidant and antiinflammatory effects of abalone intestine digest, Haliotis discus hannai in RAW 264.7 macrophages. Biotechnol Bioprocess Eng. 2012;17:475-84.

Reuter S, Gupta SC, Chaturvedi MM, Aggarwal BB. Oxidative stress, inflammation, and cancer: how are they linked? Free Radical Bio Med. 2010;49:1603-16.

Ryu B, Choi IW, Qian ZJ, Heo SJ, Kang DH, Oh C, Jeon YJ, Jang CH, Park WS, Kang $\mathrm{KH}$. Anti-inflammatory effect of polyphenol-rich extract from the red alga Callophyllis japonica in lipopolysaccharide-induced RAW 264.7 macrophages. Algae. 2014;29:343

Segovia J, Mgbemena V, Chang TH, Bose S. Kruppel-like factor 6 and inducible nitric oxide synthase regulates apoptosis during respiratory syncytial virus infection (P6198). J Immunol. 2013;190:189.14.

Sung NY, Jung PM, Yoon M, Kim JS, Ji C, Jeong HG, Lee JW, Kim JH. Antiinflammatory effect of sweetfish-derived protein and its enzymatic hydrolysate on LPS-induced RAW 264. 7 cells via inhibition of NF-kB transcription. Fish Sci. 2012;78:381-90.

Tak PP, Firestein GS. NF-kB: a key role in inflammatory diseases. J Clin Invest. 2001;107:7-11.

Wehbi VL, Taskén K. Molecular mechanisms for cAMP mediated immunoregulation in T cells_role of anchored protein kinase A signaling units. Front in Immunol. 2016;7:222.

Yeom M, Kim JH, Min JH, Hwang MK, Jung HS, Sohn Y. Xanthii fructus inhibits inflammatory responses in LPS-stimulated RAW 264.7 macrophages through suppressing NF-KB and JNK/p38 MAPK. J Ethnopharmacol. 2015:176:394-401.

Yoon HD, Jeong EJ, Choi JW, Lee MS, Park M, Yoon NY, Kim YK, Cho DM, Kim Jl, Kim HR. Anti-inflammatory effects of ethanolic extracts from Codium fragile on LPS-stimulated RAW 264.7 macrophages via nuclear factor kappaB inactivation. Fish Aquat Sci. 2011;14:267-74.

Yuan Z, Matias FB, Wu J, Liang Z, Sun Z. Koumine attenuates lipopolysaccaridestimulated inflammation in RAW264. 7 macrophages, coincidentally associated with inhibition of NF-KB, ERK and p38 pathways. Int J Mol Sci. 2016;17:430.

\section{Submit your next manuscript to BioMed Central and we will help you at every step:}

- We accept pre-submission inquiries

- Our selector tool helps you to find the most relevant journal

- We provide round the clock customer support

- Convenient online submission

- Thorough peer review

- Inclusion in PubMed and all major indexing services

- Maximum visibility for your research

Submit your manuscript at www.biomedcentral.com/submit 